Article

\title{
Auto-Tandem Catalysis in Ionic Liquids: Synthesis of 2-Oxazolidinones by Palladium-Catalyzed Oxidative Carbonylation of Propargylic Amines in $\mathrm{EmimEtSO}_{4}$
}

Raffaella Mancuso ${ }^{1, *}$, Asif Maner ${ }^{1}$, Ida Ziccarelli ${ }^{1}$, Christian Pomelli ${ }^{2}$, Cinzia Chiappe ${ }^{2}$, Nicola Della Ca ${ }^{3}$, Lucia Veltri ${ }^{1}$ and Bartolo Gabriele ${ }^{1, *}$

1 Laboratory of Industrial and Synthetic Organic Chemistry (LISOC),

Department of Chemistry and Chemical Technologies, University of Calabria, Via Pietro Bucci 12/C, 87036 Arcavacata di Rende (CS), Italy; asifncl@gmail.com (A.M.); idaziccarelli@gmail.com (I.Z.);

lucia.veltri@unical.it (L.V.)

2 Department of Pharmacy, University of Pisa, Via Bonanno 33, 56126 Pisa, Italy; christian.pomelli@gmail.com (C.P.); cinzia.chiappe@farm.unipi.it (C.C.)

3 Department of Chemistry, University of Parma, Parco Area delle Scienze 17/ A, 43124 Parma, Italy; nicola.dellaca@unipr.it

* Correspondence: raffaella.mancuso@unical.it (R.M.); bartolo.gabriele@unical.it (B.G.);

Tel.: +39-0984-49-2816 (R.M.); +39-0984-49-2815 (B.G.)

Academic Editor: Derek J. McPhee

Received: 16 June 2016; Accepted: 5 July 2016; Published: 8 July 2016

\begin{abstract}
A convenient carbonylative approach to 2-oxazolidinone derivatives carried out using an ionic liquid (1-ethyl-3-methylimidazolium ethyl sulfate, EmimEtSO ${ }_{4}$ ) as the solvent is presented. It is based on the sequential concatenation of two catalytic cycles, both catalyzed by the same metal species (auto-tandem catalysis): the first cycle corresponds to the oxidative monoaminocarbonylation of the triple bond of propargylic amines to give the corresponding 2-ynamide intermediates, while the second one involves the cyclocarbonylation of the latter to yield 2-(2-oxooxazolidin-5-ylidene)-acetamides. Reactions are carried out using a simple catalytic system consisting of $\mathrm{PdI}_{2}$ in conjunction with an excess of $\mathrm{KI}$, and the catalyst/solvent system could be recycled several times without appreciable loss of activity after extraction of the organic product with $\mathrm{Et}_{2} \mathrm{O}$.
\end{abstract}

Keywords: carbonylation; cascade catalysis; oxazolidinones; palladium

\section{Introduction}

Cascade catalysis, in which a catalytic cycle is concatenated to another eventually leading to the final product, is one of the most exciting areas of modern catalysis [1-10]. Although rather frequent in biological systems [11], where processes may be sequentially catalyzed by different enzymes, it is still relatively rare in chemical transformations, where they usually involve two concatenated cycles. A particularly interesting case, commonly referred as "auto-tandem catalysis" [9], occurs when the same catalytic system is able to catalyze both the concatenated cycles, as shown in Scheme 1.

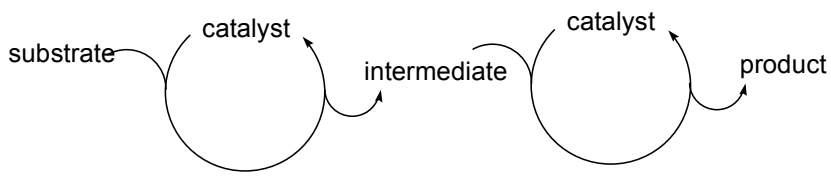

Scheme 1. The concept of "auto-tandem catalysis; the same catalyst promotes the two concatenated catalytic cycles. 
In this work, we report on the direct synthesis of 2-oxazolidinone derivatives through an auto-tandem catalysis process consisting of the concatenation of two carbonylative catalytic cycles, both catalyzed by the same catalytic system ( $\mathrm{PdI}_{2}$ in conjunction with an excess of $\left.\mathrm{KI}\right)$, performed in the ionic liquid 1-ethyl-3-methylimidazolium ethyl sulfate $\left(\right.$ EmimEtSO$\left._{4}\right)$ as an unconventional solvent.

\section{Result and Discussion}

Some years ago, we reported a novel method for the synthesis of 2-(2-oxooxazolidin5 -ylidene)acetamides 3 based on the $\mathrm{PdI}_{2} / \mathrm{KI}$-catalyzed oxidative carbonylation [12-19] of substituted propargylic amines $\mathbf{1}$, carried out in the presence of a secondary amine $\mathbf{2}$ as external nucleophile, water as a promoter, and molecular oxygen as oxidant [20]. The process, carried out at $100{ }^{\circ} \mathrm{C}$ in 1,2-dimethoxyethane (DME) as the solvent under $20 \mathrm{~atm}\left(\right.$ at $25^{\circ} \mathrm{C}$ ) of a 4:1 mixture of $\mathrm{CO} /$ air, led to the formation of a $Z / E$ mixture of 3 through the concatenation of two catalytic cycles, both catalyzed by $\mathrm{PdI}_{2} / \mathrm{KI}$, so it represented an example of auto-tandem catalysis. The first process corresponded to the oxidative aminocarbonylation of the triple bond [21] of $\mathbf{1}$ with $\mathbf{2}, \mathrm{CO}$, and $\mathrm{O}_{2}$, to give 2-ynamide intermediates I, while the second process corresponded to the water-promoted oxidative cyclocarbonylation of I to give the final products (Scheme 2; anionic iodide ligands are omitted for clarity) [20].

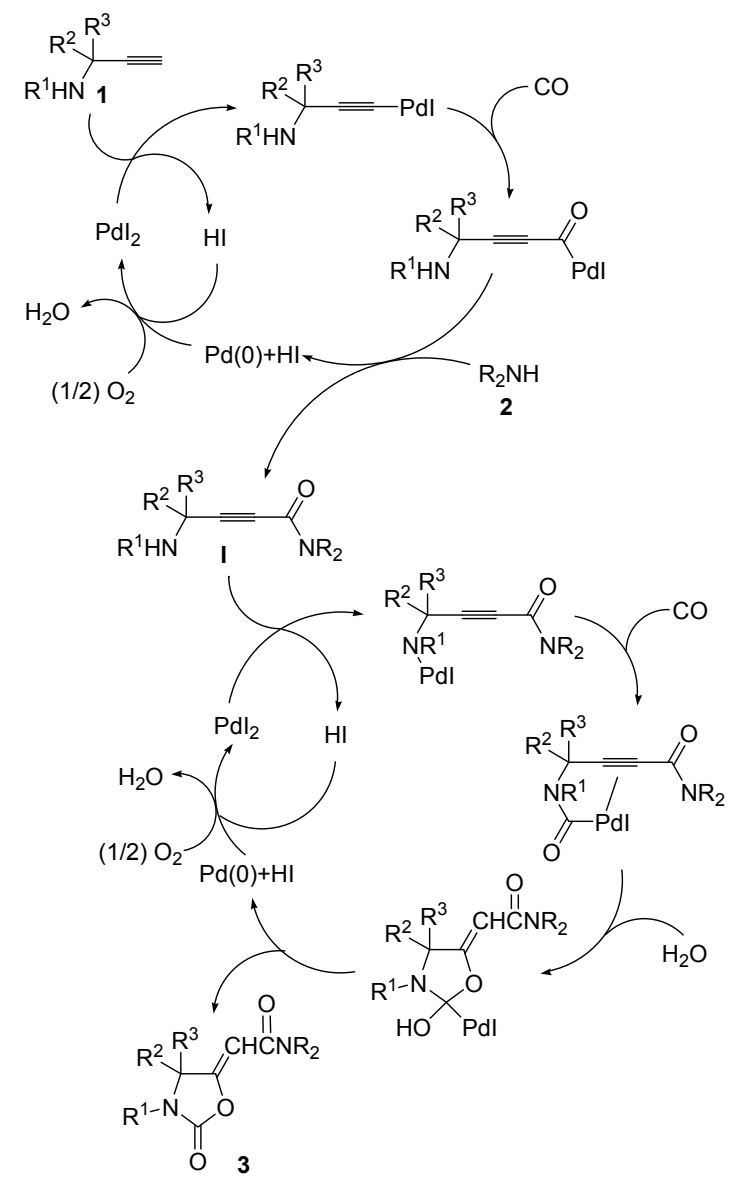

Scheme 2. Auto-tandem catalysis leading to oxazolidinones 3 by sequential $\mathrm{PdI}_{2} / \mathrm{KI}$-catalyzed oxidative monoaminocarbonylation of propargylic amines $\mathbf{1}$ to give 2-ynamide intermediates I followed by $\mathrm{PdI}_{2} / \mathrm{KI}$-catalyzed and water-promoted oxidative cyclocarbonylation of $\mathbf{I}$ (anionic iodide ligands are omitted for clarity).

Considering the importance of the class of products obtained, which are known to possess important pharmacological activities [22-25], and the current attention devoted to the possibility to 
carry out catalytic processes in ionic liquids (ILs) as safer and more environmentally friendly solvents with respect to classical VOCs [26-30], coupled to the possibility to recycle the catalytic system, we have herein explored the possibility to perform our process in the ionic liquid EmimEtSO $\mathrm{E}_{4}$.

Table 1. Synthesis of 2-(2-oxooxazolidin-5-ylidene)acetamides (3) by $\mathrm{PdI}_{2} / \mathrm{KI}$-catalyzed oxidative carbonylation of propargylic amines (1) with $\mathrm{CO}, \mathrm{O}_{2}$, and secondary amines (2) in EmimEtSO $\mathrm{E}_{4}$ and recycling experiments ${ }^{a}$.

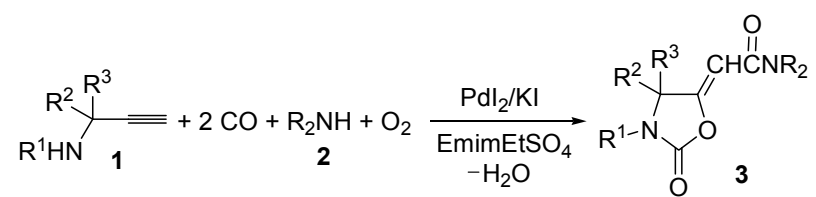

\begin{tabular}{|c|c|c|c|c|c|c|c|c|c|c|}
\hline \multirow{2}{*}{ Entry } & \multirow{2}{*}{1} & \multirow{2}{*}{2} & \multirow{2}{*}{3} & \multicolumn{7}{|c|}{ Yield of $3(\%)^{b}(Z / E \text { ratio })^{c}$} \\
\hline & & & & Run 1 & Run 2 & Run 3 & Run 4 & Run 5 & Run 6 & Run $7^{d}$ \\
\hline 1 & $\mathrm{Me}_{\mathrm{BHN}}^{\mathrm{Me}} \underbrace{=}_{\text {1a }}$ & & & $70(3.1)$ & $71(3.2)$ & $74(2.9)$ & $74(3.4)$ & $71(3.2)$ & $70(3.4)$ & $70(3.2)$ \\
\hline 2 & $1 \mathrm{a}$ & & & $74(3.1)$ & $75(3.4)$ & $73(3.2)$ & $75(3.0)$ & $74(3.3)$ & $73(3.2)$ & $74(3.3)$ \\
\hline 3 & $1 \mathrm{a}$ & & & $75(4.0)$ & $75(3.9)$ & $74(3.9)$ & $76(4.0)$ & $76(3.9)$ & $75(3.7)$ & $75(3.8)$ \\
\hline 4 & $1 \mathrm{a}$ & $\begin{array}{l}\mathrm{Et}_{2} \mathrm{NH} \\
2 \mathrm{~d}\end{array}$ & & $70(3.1)$ & $71(2.9)$ & $71(3.1)$ & $70(3.4)$ & $70(3.4)$ & $69(3.0)$ & $71(3.1)$ \\
\hline 5 & $\mathrm{Me}_{\mathrm{BnHN}}^{\mathrm{Et}}=$ & $2 a$ & & $75(2.9)$ & $75(3.4)$ & $74(3.3)$ & $75(3.0)$ & $76(3.1)$ & $74(3.1)$ & $74(3.2)$ \\
\hline 6 & & $2 a$ & & $71(6.1)$ & $74(7.2)$ & $72(6.9)$ & $74(6.4)$ & $73(7.1)$ & $75(7.3)$ & $74(7.3)$ \\
\hline 7 & $\mathrm{BuHN}_{1 \mathrm{dd}}^{\mathrm{Et}}=$ & $2 a$ & & $69(5.3)$ & $70(5.4)$ & $70(6.0)$ & $71(5.5)$ & $72(5.0)$ & $69(5.9)$ & $72(5.6)$ \\
\hline 8 & $1 d$ & $2 d$ & & $74 \underset{\mathrm{e}}{(6.4)}$ & $\begin{array}{c}76(5.9) \\
\mathrm{e}\end{array}$ & $76 \underset{\mathrm{e}}{76.0)}$ & $75 \underset{\mathrm{e}}{76.3)}$ & $74 \underset{\mathrm{e}}{(6.2)}$ & $75 \underset{\mathrm{e}}{(6.1)}$ & $74(6.0)^{\mathrm{e}}$ \\
\hline 9 & & $2 a$ & & $69(4.3)$ & $72(4.5)$ & 71 (4.5) & $71(4.9)$ & $72(4.5)$ & $72(4.5)$ & $70(4.8)$ \\
\hline
\end{tabular}

a All reactions were carried out in the presence of $\mathrm{PdI}_{2}, \mathrm{KI}$, and $\mathrm{H}_{2} \mathrm{O}$ at $100{ }^{\circ} \mathrm{C}$ under 20 atm $\left(\right.$ at $25^{\circ} \mathrm{C}$ ) of a $4: 1$ mixture $\mathrm{CO} /$ air, in $\mathrm{EmimEtSO}_{4}$ for $24 \mathrm{~h}$ with a substrate concentration of $0.5 \mathrm{mmol}$ of $\mathbf{1}$ per $\mathrm{mL}$ of ionic liquid. The $\mathrm{H}_{2} \mathrm{O}: 2: 1: \mathrm{KI}_{\mathrm{PdI}}$ molar ratio was 250:250:50:10:1. Conversion of $\mathbf{1}$ was quantitative in all cases. ${ }^{\mathrm{b}}$ Isolated yield $(Z+E)$ based on starting $1 .{ }^{c}$ Determined by isolation of the pure diastereoisomers. ${ }^{d}$ Run 1 corresponds to the 1st experiment, the next runs to recycles. See text for details. ${ }^{\mathrm{e}}$ Determined by GLC. The $E$ isomer could be isolated at the pure state after column chromatography, while the $\mathrm{Z}$ isomer was isolated with a purity of ca. $60 \%$ (by GLC). See the Experimental Section for details. 
Our first experiment was carried out using $N$-benzyl-2-methylbut-3-yn-2-amine (1a) as the substrate. This compound was allowed to react with $\mathrm{CO}$, morpholine (2a), $\mathrm{O}_{2}$, and water in the presence of the catalytic system $\mathrm{PdI}_{2} / \mathrm{KI}$ under the following conditions: $\mathrm{PdI}_{2} / \mathrm{KI} / \mathbf{1 a} / \mathbf{2 a} / \mathrm{H}_{2} \mathrm{O}$ molar ratio $=1: 10: 50: 250: 250, \mathrm{~T}=100{ }^{\circ} \mathrm{C}, \mathrm{P}(\mathrm{CO})=16 \mathrm{~atm}, \mathrm{P}(\mathrm{air})=4 \mathrm{~atm}, \mathrm{EmimEtSO}_{4}$ as the solvent $(0.5 \mathrm{mmol}$ of 1a per mL of solvent) (Table 1, entry 1, run 1). After $24 \mathrm{~h}$, the reaction crude was extracted several times with diethyl ether and the collected ethereal phases analyzed by TLC, GLC and GC-MS, who revealed the formation of two products whose MS spectra were compatible with the expected isomeric oxazolidinone products $3 \mathbf{a a}-Z$ and $3 a a-E$. The two isomers were isolated by column chromatography and their structure confirmed by IR, ${ }^{1} \mathrm{H}-\mathrm{NMR}$ and ${ }^{13} \mathrm{C}-\mathrm{NMR}$ spectroscopies $(Z / E$ ratio $=3.1: 1$, total yield $=70 \%$ ). The yield turned out to be lower using only 2 equiv of 2 a instead of 5 (total yield $=55 \%$ ). These results confirmed the possibility to carry out the auto-tandem catalysis process leading to oxazolidinones 3 in an ionic liquid (IL) as unconventional solvent. We accordingly verified the possibility to recycle the catalyst/solvent system. Thus, the residue obtained after product extraction with diethyl ether (still containing the catalyst dissolved in the IL), after drying under vacuum (to eliminate the residual diethyl ether), was used again by adding to it fresh propargylamine $1 \mathrm{a}$ and morpholine (2a) (1:5 ratio). After stirring at $100{ }^{\circ} \mathrm{C}$ for $24 \mathrm{~h}$, 3aa was obtained again as a 3.2:1 $\mathrm{Z} / \mathrm{E}$ mixture in $71 \%$ total isolated yield (Table 1 , entry 1 , run 2 ), after extraction with diethyl ether. The recycling procedure was then successfully repeated up to six times.

In order to assess the generality of the method, the reaction was then performed using different combinations of propargylic amines $\mathbf{1 a}-\mathbf{e}$ and secondary amines $\mathbf{2 a}-\mathbf{d}$, with the results shown in Table 1 , entries 2-9. As can be seen from Table 1, the method could be successfully applied to propargylic amines bearing various alkyl groups $\alpha$ to the triple bond, including simple alkyl groups (such as methyl and ethyl $(\mathbf{1} \mathbf{a}, \mathbf{1} \mathbf{b}$, and $\mathbf{1 d})$ and a cyclic chain such as $\left.-\left(\mathrm{CH}_{2}\right)_{4},(\mathbf{1 c})\right)$, different groups on nitrogen (such as benzyl (1a-c) and butyl (1e, 1f)), and different nucleophilic secondary amines, both cyclic (as in the case of morpholine (2a), piperidine (2b), and pyrrolidine (2c)) and acyclic (as in the case of diethylamine $\mathbf{( 2 d ) ) . ~ I n ~ a l l ~ c a s e s , ~ g o o d ~ y i e l d s ~ o f ~ t h e ~ c o r r e s p o n d i n g ~ 2 - ( 2 - o x o o x a z o l i d i n - 5 - y l i d e n e ) a c e t a m i d e s ~} 3$ were obtained $(69 \%-76 \%)$, and the $\mathrm{PdI}_{2} / \mathrm{KI} / \mathrm{EmimEtSO}_{4}$ system could be conveniently recycled up to six times without loss of activity.

\section{Experimental Section}

\subsection{General Information}

Chemicals were purchased from Sigma-Aldrich Italia (Milano, Italy) and were used as such without further purification. Melting points were taken on a Reichert Thermovar apparatus and are uncorrected. ${ }^{1} \mathrm{H}-\mathrm{NMR}$ and ${ }^{13} \mathrm{C}-\mathrm{NMR}$ spectra were recorded at $25{ }^{\circ} \mathrm{C}$ in $\mathrm{CDCl}_{3}$ solutions with a Bruker DPX Avance 300 spectrometer (Bruker Italia, Milano, Italy) operating at $300 \mathrm{MHz}$ and $75 \mathrm{MHz}$, respectively, with $\mathrm{Me}_{4} \mathrm{Si}$ as internal standard. IR spectra were taken with a JASCO FT-IR 4200 spectrometer (Jasco Europe s.r.l., Cremella, Lecco, Italy). Mass spectra were obtained using a Shimadzu QP-2010 GC-MS apparatus (Shimadzu Italia, Milano, Italy) at $70 \mathrm{eV}$ ionization voltage. Microanalyses were carried out with a Thermo-Fischer Elemental Analyzer Flash 2000 (Fischer Scientific Italia, Rodani, Milano, Italy). All reactions were analyzed by TLC (Merck Italy, Vimodrone, Milano, Italy) on silica gel 60 F254 (Merck Italy) or on neutral alumina (Merck Italy) and by GLC using a Shimadzu GC-2010 gas chromatograph (Shimadzu Italia) and capillary columns with polymethylsilicone $+5 \%$ polyphenylsilicone as the stationary phase (HP-5). Column chromatography was performed on neutral alumina 90 (Merck Italy, 70-230 mesh). Evaporation refers to the removal of solvent under reduced pressure.

\subsection{Preparation of Substrates}

Starting propargylic amines 1a-e were prepared and characterized as already described [20]. 


\subsection{Preparation of $\mathrm{EmimEtSO}_{4}$}

Ionic liquid 1-ethyl-3-methylimidazolium ethyl sulfate $\left(\mathrm{EmimEtSO}_{4}\right)$ was prepared as previously described [31].

3.4. General Procedure for the PdI $/ 2 / K I$-Catalyzed Oxidative Carbonylation of Propargylic Amines (1) with CO, $\mathrm{O}_{2}$, and Secondary Amines (2) in EmimEtSO 4 and Recycling Experiments

A $35 \mathrm{~mL}$ stainless steel autoclave was charged with $\mathrm{PdI}_{2}(8.3 \mathrm{mg}, 0.023 \mathrm{mmol}), \mathrm{KI}(38.3 \mathrm{mg}$, $0.23 \mathbf{m m o l})$, the starting propargylic amine $\mathbf{1}(\mathbf{1 a}, 199.0 \mathrm{mg} ; \mathbf{1 b}, 215.0 \mathrm{mg} ; \mathbf{1 c}, 245.0 \mathrm{mg} ; \mathbf{1 d}, 176.0 \mathrm{mg}$; 1e, $206.0 \mathrm{mg}$; $1.15 \mathrm{mmol}$ ) and the amine 2 (2a, $501.0 \mathrm{mg}$; $2 \mathbf{b}, 490.0 \mathrm{mg}$; 2c, $409.0 \mathrm{mg}$; 2d, $420.6 \mathrm{mg}$; $5.75 \mathrm{mmol})$ in $\mathrm{EmimEtSO}_{4}(2.3 \mathrm{~mL})$. Water $(103.5 \mu \mathrm{L}, 5.75 \mathrm{mmol})$ was then added and the autoclave was sealed, and pressurized at $20 \mathrm{~atm}\left(16 \mathrm{~atm} \mathrm{CO}\right.$ and $4 \mathrm{~atm}$ Air). After stirring at $100{ }^{\circ} \mathrm{C}$ for $24 \mathrm{~h}$, the autoclave was cooled and degassed. The mixture was then extracted with $\mathrm{Et}_{2} \mathrm{O}(6 \times 4 \mathrm{~mL})$, and the residue (still containing the catalyst and water dissolved in the ionic liquid) was used as such for the next recycle (see below). The collected ethereal phases were concentrated and the products purified by column chromatography on neutral alumina using as the eluent hexane:AcOEt from 95:5 to 6:4 (the $E$ isomers were eluted first in all cases). (3aa- $E, 64.8 \mathrm{mg}, 17 \%$; 3aa- $Z, 201.4 \mathrm{mg}, 53 \%$; 3ab- $E, 68.0 \mathrm{mg}$, $18 \%$; 3ab-Z, $211.5 \mathrm{mg}, 56 \%$; 3ac- $E$, $54.5 \mathrm{mg}, 15 \%$; 3ac-Z, $216.7 \mathrm{mg}, 60 \%$; 3ad- $E, 61.9 \mathrm{mg}, 17 \%$; 3ad-Z, $192.8 \mathrm{mg}, 53 \%$; 3ba- $E$, $75.2 \mathrm{mg}, 19 \%$; 3ba-Z, $221.8 \mathrm{mg}$, 56\%; 3ca-E, $42.6 \mathrm{mg}, 10 \%$; 3ca-Z, 259.9, 61\% mg; 3da- $E$, 39.3 mg, 11\%; 3da-Z, 207.0 mg, 58\%; 3dd- $E$, 34.1 mg, 10\%; 3ea- $E, 50.3$ mg, 13\%; 3ea-Z, 216.7 mg, $56 \%$ ). Note: Product $3 \mathrm{dd}-Z$ could not be isolated at the pure state by column chromatography, and the GLC analysis evidenced a purity of ca. $60 \%$. The GLC-MS analysis was compatible with the proposed structure and ${ }^{1} \mathrm{H}-\mathrm{NMR}$ spectrum of the crude product evidenced a peak at 5.19 , compatible with a $\mathrm{Z}$ stereochemistry. For testing recycling of the catalyst, after removal of $\mathrm{Et}_{2} \mathrm{O}$ under vacuum, the residue obtained as described above, still containing the catalyst dissolved in the ionic liquid, was transferred into the autoclave. The starting material $1(1.15 \mathrm{mmol})$, the amine $2(5.75 \mathrm{mmol})$ and $\mathrm{H}_{2} \mathrm{O}(103.5 \mu \mathrm{L}$, $5.75 \mathrm{mmol}$ ) was added, and then the same procedure described above was followed.

\subsection{Characterization of Products}

Oxazolidinones 3aa- $Z$, 3aa- $E$, 3ab-Z, 3ab- $E$, 3ad- $Z$, 3ad- $E$, 3ba- $Z$, 3ba- $E$, 3ca- $Z$, 3ca- $E$, 3da- $Z$, 3da- $E$, 3ea- $Z$, 3ea- $E$, were characterized by comparison with the characterization data already reported by us [20]. All the other products were fully characterized by MS spectrometry, IR, ${ }^{1} \mathrm{H}-\mathrm{NMR}$ and ${ }^{13} \mathrm{C}-\mathrm{NMR}$ spectroscopies, and elemental analysis, as reported below. Copies of ${ }^{1} \mathrm{H}-\mathrm{NMR}$ and ${ }^{13} \mathrm{C}-\mathrm{NMR}$ spectra for all products are given in the Supplementary Materials.

(E)-3-Benzyl-4,4-dimethyl-5-(2-oxo-2-pyrrolidin-1-ylethylidene)-oxazolidin-2-one (3ac-E). White solid, m.p. $=124-125^{\circ} \mathrm{C} . \operatorname{IR}(\mathrm{KBr}): v=1779(\mathrm{~s}), 1664(\mathrm{~m}), 1611(\mathrm{~m}), 1404(\mathrm{~m}), 1346(\mathrm{w}), 1194(\mathrm{w}), 709(\mathrm{w}) \mathrm{cm}^{-1}$; ${ }^{1} \mathrm{H}-\mathrm{NMR}\left(\mathrm{CDCl}_{3}\right): \delta=7.38-7.26\left(\mathrm{~m}, 5 \mathrm{H}\right.$, aromatic), $5.83(\mathrm{~s}, 1 \mathrm{H},=\mathrm{CH}), 4.47\left(\mathrm{~s}, 2 \mathrm{H}, \mathrm{CH}_{2} \mathrm{Ph}\right), 3.51-3.40$ (m, $4 \mathrm{H}$, pyrrolidine ring), $2.02-1.82\left(\mathrm{~m}, 4 \mathrm{H}\right.$, pyrrolidine ring), $1.64(\mathrm{~s}, 6 \mathrm{H}, 2 \mathrm{Me}) ;{ }^{13} \mathrm{C}-\mathrm{NMR}\left(\mathrm{CDCl}_{3}\right)$ : $\delta=165.4,162.9,153.6,137.3,128.7,127.8,96.8,64.4,47.2,45.7,43.8,26.2,24.4,23.9$; GC-MS $m / z=314$ (11) $\left[\mathrm{M}^{+}\right], 299$ (5), 286 (2), 255 (1), 244 (2), 223 (13), 216 (2), 181 (2), 166 (4), 146 (2), 140 (8), 132 (2), 112 (2), 98 (9), 91 (100); anal. calcd for $\mathrm{C}_{18} \mathrm{H}_{22} \mathrm{~N}_{2} \mathrm{O}_{3}$ (314.38): C, 68.77; H, 7.05; N, 8.91; found C, 68.75; H, 7.04; N, 8.89 .

(Z)-3-Benzyl-4,4-dimethyl-5-(2-oxo-2-pyrrolidin-1-ylethylidene)-oxazolidin-2-one (3ac-Z). Yellow solid, m.p. $=105-106{ }^{\circ} \mathrm{C} . \mathrm{IR}(\mathrm{KBr}): v=1780$ (s), 1685 (s), $1616(\mathrm{~m}), 1438$ (m), 1401 (m), 1225 (w), 1036 (m), $754(\mathrm{w}) \mathrm{cm}^{-1} ;{ }^{1} \mathrm{H}-\mathrm{NMR}\left(\mathrm{CDCl}_{3}\right): \delta=7.48-7.22(\mathrm{~m}, 5 \mathrm{H}$, aromatic), $5.21(\mathrm{~s}, 1 \mathrm{H},=\mathrm{CH}), 4.48(\mathrm{~s}, 2 \mathrm{H}$, $\left.\mathrm{CH}_{2} \mathrm{Ph}\right), 3.59-3.43(\mathrm{~m}, 4 \mathrm{H}$, pyrrolidine ring), 2.03-1.84 (m, 4H, pyrrolidine ring), $1.35(\mathrm{~s}, 6 \mathrm{H}, 2 \mathrm{Me})$; ${ }^{13} \mathrm{C}-\mathrm{NMR}\left(\mathrm{CDCl}_{3}\right): \delta=162.7,160.5,153.8,137.1,128.8,128.0,127.8,94.6,62.4,47.1,45.7,44.2,27.5,25.9$, 24.4; GC-MS m/z = 314 (8) [M+1, 299 (4), 286 (1), 255 (1), 243 (3), 223 (11), 216 (1), 181 (2), 166 (2), 147 (4), 140 (6), 132 (1), 112 (2), 98 (7), 91 (100); anal. calcd for $\mathrm{C}_{18} \mathrm{H}_{22} \mathrm{~N}_{2} \mathrm{O}_{3}$ (314.38): C, 68.77; $\mathrm{H}, 7.05 ; \mathrm{N}, 8.91$; found $\mathrm{C}, 68.78 ; \mathrm{H}, 7.03 ; \mathrm{N}, 8.92$. 
(E)-2-(3-Butyl-4-ethyl-4-methyl-2-oxooxazolidin-5-ylidene)-N,N-diethylacetamide (3dd-E). Yellow oil. IR (film): $v=1786(\mathrm{~s}), 1687(\mathrm{~m}), 1618(\mathrm{~m}), 1401(\mathrm{w}), 1052(\mathrm{~m}), 1082(\mathrm{~m}) \mathrm{cm}^{-1} ;{ }^{1} \mathrm{H}-\mathrm{NMR}\left(\mathrm{CDCl}_{3}\right): \delta=5.92$ $(\mathrm{s}, 1 \mathrm{H},=\mathrm{CH}), 3.46-3.30\left(\mathrm{~m}, 4 \mathrm{H}, 2 \mathrm{NCH}_{2}\right), 3.29-3.16(\mathrm{~m}, 1 \mathrm{H}, \mathrm{CHH}), 3.06-2.93(\mathrm{~m}, 1 \mathrm{H}, \mathrm{CHH}), 2.76-2.60$ $(\mathrm{m}, 1 \mathrm{H}, \mathrm{CHH}), 1.70-1.53\left(\mathrm{~m}, 3 \mathrm{H}, \mathrm{CH}_{2}+\mathrm{CHH}\right), 1.42-1.30\left(\mathrm{~m}, 2 \mathrm{H}, \mathrm{CH}_{2}\right), 1.66(\mathrm{~s}, 3 \mathrm{H}, \mathrm{Me}), 1.19(\mathrm{t}, J=7.2$, $3 \mathrm{H}, \mathrm{Me}), 1.14(\mathrm{t}, J=7.1,3 \mathrm{H}, \mathrm{Me}), 0.95(\mathrm{t}, J=7.4,3 \mathrm{H}, \mathrm{Me}), 0.79(\mathrm{t}, J=7.4,3 \mathrm{H}, \mathrm{Me}) ;{ }^{13} \mathrm{C}-\mathrm{NMR}\left(\mathrm{CDCl}_{3}\right)$ : $\delta=164.1,163.5,153.8,96.7,68.0,43.0,40.5,40.0,31.1,28.5,23.7,20.3,14.5,13.7,13.1,8.2$; GC-MS

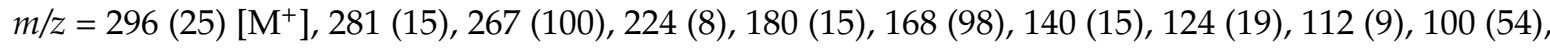
72 (71); anal. calcd for $\mathrm{C}_{16} \mathrm{H}_{28} \mathrm{~N}_{2} \mathrm{O}_{3}$ (296.41): C, 64.83; $\mathrm{H}, 9.52 ; \mathrm{N}, 9.45$; found $\mathrm{C}, 64.80 ; \mathrm{H}, 9.54 ; \mathrm{N}, 9.42$.

(Z)-2-(3-Butyl-4-ethyl-4-methyl-2-oxooxazolidin-5-ylidene)-N,N-diethylacetamide (3dd-Z). Yellow oil, purity:

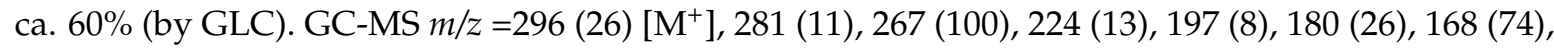
138 (13), 124 (33), 112 (14), 100 (37), 72 (89).

\section{Conclusions}

In conclusion, we have shown that it is possible to successfully perform the $\mathrm{PdI}_{2} / \mathrm{KI}$-catalyzed auto-tandem catalysis oxidative carbonylative process leading to oxazolidone derivatives 3 in an ionic liquid, such as EmimEtSO 4 , as unconventional solvent, and that the catalyst/solvent system can be easily recycled several times without loss of activity.

Supplementary Materials: Supplementary materials can be accessed at: http://www.mdpi.com/1420-3049/ 21/7/897/s1.

Acknowledgments: This research work was partially supported by MIUR PON R\&C 2007-2013 Project “DIRECT FOOD" cod. PON01_00878 (research grant to R.M.).

Author Contributions: All authors contributed equally to this work.

Conflicts of Interest: The authors declare no conflict of interest.

\section{Abbreviations}

The following abbreviations are used in this manuscript:

$\begin{array}{ll}\mathrm{DME} & \text { 1,2-dimethoxyethane } \\ \mathrm{EmimEtSO}_{4} & \text { 1-ethyl-3-methylimidazolium ethyl sulfate } \\ \mathrm{Et}_{2} \mathrm{O} & \text { diethyl ether } \\ \mathrm{GC} & \text { gas chromatograph } \\ \text { GC-MS } & \text { gas chromatograph/mass spectrometer } \\ \text { GLC } & \text { gas-liquid chromatography } \\ \text { GLC-MS } & \text { gas-liquid chromatography/mass spectrometry } \\ \mathrm{ILs} & \text { Ionic Liquids } \\ \mathrm{TLC} & \text { thin layer chromatography } \\ \mathrm{MS} & \text { mass } \\ \text { NMR } & \text { nuclear magnetic resonance } \\ \text { VOCs } & \text { Volatile Organic Compounds }\end{array}$

\section{References}

1. Sun, S.; He, J.; Qu, M.; Li, K. Progress of cooperative catalysis in organic synthesis. Chin. J. Org. Chem. 2015, 35, 1250-1259. [CrossRef]

2. Dhakshinamoorthy, A.; Garcia, H. Cascade reactions catalyzed by metal organic frameworks. ChemSusChem 2014, 7, 2392-2410. [CrossRef] [PubMed]

3. Filice, M.; Palomo, J.M. Cascade reactions catalyzed by bionanostructures. ACS Catal. 2014, 4, 1588-1598. [CrossRef]

4. Ball, C.J.; Willis, M.C. Cascade palladium- and copper-catalysed aromatic heterocycle synthesis: The emergence of general precursors. Eur. J. Org. Chem. 2013, 425-441. [CrossRef]

5. Vlaar, T.; Ruijter, E.; Orru, R.V.A. Recent advances in palladium-catalyzed cascade cyclizations. Adv. Synth. Catal. 2011, 353, 809-841. [CrossRef]

6. Ambrosini, L.M.; Lambert, T.H. Multicatalysis: Advancing synthetic efficiency and inspiring discovery. ChemCatChem 2010, 2, 1373-1380. [CrossRef] 
7. Grondal, C.; Jeanty, M.; Enders, D. Organocatalytic cascade reactions as a new tool in total synthesis. Nat. Chem. 2010, 2, 167-178. [CrossRef] [PubMed]

8. Zhou, J. Recent Advances in Multicatalyst Promoted Asymmetric Tandem Reactions. Chem. Asian J. 2010, 5 , 422-434. [CrossRef] [PubMed]

9. Shindoh, N.; Takemoto, Y.; Takasu, K. Auto-tandem catalysis: A single catalyst activating mechanistically distinct reactions in a single reactor. Chem. Eur. J. 2009, 15, 12168-12179. [CrossRef] [PubMed]

10. Wender, P.A.; Miller, B.L. Synthesis at the molecular frontier. Nature 2009, 460, 197-201. [CrossRef] [PubMed]

11. Wheeldon, I.; Minteer, S.D.; Banta, S.; Barton, S.C.; Atanassov, P.; Sigman, M. Substrate channelling as an approach to cascade reactions. Nat. Chem. 2016, 8, 299-309. [CrossRef] [PubMed]

12. Veltri, L.; Grasso, G.; Rizzi, R.; Mancuso, R.; Gabriele, B. Palladium-catalyzed carbonylative multicomponent synthesis of functionalized benzimidazothiazoles. Asian J. Org. Chem. 2016, 5, 560-567. [CrossRef]

13. Mancuso, R.; Raut, D.S.; Marino, N.; de Luca, G.; Giordano, C.; Catalano, S.; Barone, I.; Andò, S.; Gabriele, B. A palladium-catalyzed carbonylation approach to eight-membered lactam derivatives with antitumor activity. Chem. Eur. J. 2016, 22, 3053-3064. [CrossRef] [PubMed]

14. Veltri, L.; Mancuso, R.; Altomare, A.; Gabriele, B. Divergent multicomponent tandem palladium-catalyzed aminocarbonylation-cyclization approaches to functionalized imodazothiazinones and imidazothiazoles. ChemCatChem 2015, 7, 2206-2213. [CrossRef]

15. Mancuso, R.; Raut, D.S.; Della Ca', N.; Fini, F.; Carfagna, C.; Gabriele, B. Catalytic oxidative carbonylation of amino moieties to ureas, oxamides, 2-oxazolidinones, and benzoxazolones. ChemSusChem 2015, 8, 2204-2211. [CrossRef] [PubMed]

16. Gabriele, B.; Veltri, L.; Mancuso, R.; Carfagna, C. Cascade reactions: a multicomponent approach to functionalized indane derivatives by a tandem palladium-catalyzed carbamoylation/carbocyclization process. Adv. Synth. Catal. 2014, 356, 2547-2558. [CrossRef]

17. Mancuso, R.; Ziccarelli, I.; Armentano, D.; Marino, N.; Giofrè, S.V.; Gabriele, B. Divergent palladium iodide catalyzed multicomponent carbonylative approaches to functionalized isoindolinone and isobenzofuranimine derivatives. J. Org. Chem. 2014, 79, 3506-3518. [CrossRef] [PubMed]

18. Gabriele, B.; Mancuso, R.; Salerno, G. Oxidative carbonylation as a powerful tool for the direct synthesis of carbonylated heterocycles. Eur. J. Org. Chem. 2012, 6825-6839. [CrossRef]

19. Zhu, C.; Yang, B.; Backvall, J.-E. Highly selective cascade C-C bond formation via palladium-catalyzed oxidative carbonylation-carbocyclization-carbonylation-alkynylation of enallenes. J. Am. Chem. Soc. 2015, 137, 11868-11871. [CrossRef] [PubMed]

20. Gabriele, B.; Plastina, P.; Salerno, G.; Mancuso, R.; Costa, M. An unprecedented Pd-catalyzed, water-promoted sequential oxidative aminocarbonylation-cyclocarbonylation process leading to 2-oxazolidinones. Org. Lett. 2007, 9, 3319-3322. [CrossRef] [PubMed]

21. Gabriele, B.; Salerno, G.; Veltri, L.; Costa, M. Synthesis of 2-ynamides by direct palladium-catalyzed oxidative aminocarbonylation of alk-1-ynes. J. Organomet. Chem. 2001, 622, 84-88. [CrossRef]

22. Cattaneo, D.; Alffenaar, J.-W.; Neely, M. Drug monitoring and individual dose optimization of antimicrobial drugs: oxazolidinones. Expert Opin. Drug Metab. Toxicol. 2016, 12, 533-544. [CrossRef] [PubMed]

23. Phillips, O.A.; Sharaf, L.H. Oxazolidinone antimicrobials: A patent review (2012-2015). Expert Opin. Ther. Patents 2016, 26, 591-605. [CrossRef] [PubMed]

24. Douros, A.; Grabowski, K.; Stahlmann, R. Drug-drug interactions and safety of linezolid, tedizolid, and other oxazolidinones. Expert Opin. Drug Metab. Toxicol. 2015, 11, 1849-1859. [CrossRef] [PubMed]

25. Renslo, A.R. Antibacterial oxazolidinones: emerging structure-toxicity relationships. Expert Rev. Anti-Infect. Ther. 2010, 8, 565-574. [CrossRef] [PubMed]

26. Wang, S.; Wang, X. Imidazolium Ionic Liquids, Imidazolylidene Heterocyclic Carbenes, and Zeolitic Imidazolate Frameworks for $\mathrm{CO}_{2}$ Capture and Photochemical Reduction. Angew. Chem. Int. Ed. 2016, 55, 2308-2320. [CrossRef] [PubMed]

27. Thomas, P.A.; Marvey, B.B. Room Temperature Ionic Liquids as Green Solvent Alternatives in the Metathesis of Oleochemical Feedstocks. Molecules 2016, 21, 184. [CrossRef] [PubMed]

28. Laali, K.K. Ionic liquids as novel media for electrophilic/onium ion chemistry and metal-mediated reactions: A progress summary. Arkivoc 2016. [CrossRef]

29. Kuchenbuch, A.; Giernoth, R. Ionic Liquids beyond Simple Solvents: Glimpses at the State of the Art in Organic Chemistry. ChemistryOpen 2015, 4, 677-681. [CrossRef] [PubMed] 
30. Hajipour, A.R.; Rafiee, F. Recent Progress in Ionic Liquids and their Applications in Organic Synthesis. Org. Prep. Proced. Int. 2015, 47, 1-60. [CrossRef]

31. Holbrey, J.D.; Reichert, W.M.; Swatloski, R.P.; Broker, G.A.; Pitner, W.R.; Seddon, K.R.; Rogers, R.D. Efficient, halide free synthesis of new, low cost ionic liquids: 1,3-Dialkylimidazolium salts containing methyl- and ethyl-sulfate anions. Green Chem. 2002, 4, 407-413. [CrossRef]

Sample Availability: Samples of the compounds 3 are available from the authors.

(C) 2016 by the authors; licensee MDPI, Basel, Switzerland. This article is an open access article distributed under the terms and conditions of the Creative Commons Attribution (CC-BY) license (http://creativecommons.org/licenses/by/4.0/). 